\title{
Between Pocket Forest Wilderness and Restored Rural Arcadia: Optimizing the Use of a Feral Woodland Enclave in Urban Environment
}

\author{
Andrzej Bobiec ${ }^{1, *}$, Agata Ćwik ${ }^{1}$ (D) Agata Gajdek ${ }^{2}$, Tomasz Wójcik ${ }^{1}$ and Maria Ziaja ${ }^{3}$ (D) \\ 1 Department of Nature Protection and Landscape Ecology, Institute of Agricultural Sciences, Land \\ Management and Environmental Protection, College of Natural Sciences, University of Rzeszów, ul. \\ Zelwerowicza 4, 35-601 Rzeszów, Poland; acwik@ur.edu.pl (A.Ć.); tomaszwojcik@ur.edu.pl (T.W.) \\ 2 Department of Landscape Architecture, Institute of Agricultural Sciences, Land Management and \\ Environmental Protection, College of Natural Sciences, University of Rzeszów, ul. Zelwerowicza 4, \\ 35-601 Rzeszów, Poland; agajdek@ur.edu.pl \\ 3 Institute of Physical Culture Studies, Medical College, University of Rzeszów, ul. Cicha 2a, \\ 35-326 Rzeszów, Poland; mziaja@ur.edu.pl \\ * Correspondence: a_bobiec@ur.edu.pl
}

Citation: Bobiec, A.; Ćwik, A.; Gajdek, A.; Wójcik, T.; Ziaja, M. Between Pocket Forest Wilderness and Restored Rural Arcadia: Optimizing the Use of a Feral Woodland Enclave in Urban Environment. Forests 2021, 12, 1173 https://doi.org/10.3390/f12091173

Academic Editor: Isabella De Meo

Received: 27 July 2021

Accepted: 26 August 2021

Published: 30 August 2021

Publisher's Note: MDPI stays neutral with regard to jurisdictional claims in published maps and institutional affiliations.

Copyright: (c) 2021 by the authors. Licensee MDPI, Basel, Switzerland. This article is an open access article distributed under the terms and conditions of the Creative Commons Attribution (CC BY) license (https:// creativecommons.org/licenses/by/ $4.0 /)$.

\begin{abstract}
An eight-hectare forest reserve in the centre of the metropolitan area in SE Poland was investigated for the effects of its management in relation to its purpose-protection of old Quercus robur L. trees. This local issue corresponds to a wider debate on the role of urban forests in contemporary societies. The study embraced (1) oak stand history—stand mapping and dendrochronology, historical maps' analysis; (2) vegetation trends-undergrowth and ground layer analysis; and (3) visitors' opinions on the reserve's use-interview. The dendroecological analysis corroborates the landscape's history emerging from the 1700s-1900s maps. The reserve is a feral park established in the early 1900s on the abandoned agricultural, partly wooded landscape. Under the current regime, shade-tolerant trees continue gaining advantage over older oaks, preventing their regeneration, whilst the herb layer, due to the reserve's isolation remains poor and polluted by alien species. The non-intervention approach does not allow the reserve's objective to be met. We recommend the restoration of features of semi-open silvopastoral landscape. This would correspond with both local eco-history and the dominating preference of the interviewed visitors. Such "bio-cultural refugia" should become key knowledge centres of the natural, cultural, and economic importance of the "working rural landscape", fostering urban care for the countryside.
\end{abstract}

Keywords: agricultural landscape; bio-ecological refugia; dendroecological reconstruction; ecological history; ecosystem services; human preferences; protection regime; Quercus robur; urban forest; vegetation dynamics

\section{Introduction}

With the world-wide growth of urban population [1], there is an increasing interest of societies in urban forests [2,3]. Due to the specific characteristics of the urban environment (very high population density, pollution, noise, heat), urban forests are particularly expected to mitigate the environmental downsides of urban life. Thus, in contrast to most of the countryside forests, regulatory and cultural ecosystem services have been given much higher priority in metropolitan areas than the provision of forest commodities [4]. However, as the historical evidence shows, urban forests are not a recent invention. Rackham [5] emphasized that historic woodlands of Europe substantially differed from the contemporary woodlands-whether economically used or preserved in nature reserves. Most of the British woods, being integral parts of larger agricultural (agri-silvopastoral) landscapes, were either regularly grazed by livestock or managed as coppice woods (often with standards). Many ancient woodlands, such as Windsor in England or Le Bois de Boulogne in 
France have a very long history of recreational use. A very important woodland category was "deer parks", vast, partly wooded, fenced areas sustaining dense game populations [5]. Besides providing venison, commonly used for sport and prestige hunting by kings and aristocracy, they were an exclusive equivalent of modern "democratic" recreational forests.

However, the true dawn of urban forests dedicated to the improvement of the quality of urban life coincides with the development of dense industrial agglomerations, feeding the industrial revolution. Numerous European examples of vast metropolitan public wooded areas show that the awareness of forests' contribution to the quality of life in urbanindustrial settings had long anticipated the emergence of the very concept of "ecosystem services" [6,7]. Large city parks set in the nineteenth-century's industrial centres (such as Sefton Park in Liverpool in England [8]) were thought to improve the life hygiene of the poor working class. One of the most famous urban forests of the world can be considered New York City's Central Park, designed and developed in the 1850s-1860s. This 341-hectares rectangular block of green infrastructure is annually visited by ca. 40 million visitors, providing them an opportunity of recreation and rest in a beautiful, wooded landscape in the middle of Manhattan [9]. There are several noticeable examples of almost continuous urban-woodland interface throughout entire or substantial parts of metropolitan areas, such as National Urban Park in Stockholm, Sweden [10] and Houston's Urban Forest, TX, USA [11], immensely contributing to the ambient social, economic, and cultural cities' environment. In recent decades, one can observe more pro-active approaches to urban and peri-urban green zones, including urban woodlands. For instance, in Greece, livestock grazing and prescribed burning are used in the management of the urban-rural interface [12], reducing the risk of devastating wildfires. Urban grazing is also advised as a potentially important landscaping tool, which may contribute to the re-integration of food production with human life space [13].

According to Ranacher et al. [14], forests are essential for contemporary Europeans as an environment where they can fulfil their need to "be in nature" and to "be in wilderness", which has a positive influence on human physical and psychological well-being. However, different people apply various, sometimes very different forest blueprints, imagining their "ideal nature" or "wilderness". Thus, the "being in wild nature" desire, for a "common man", usually means something very different from an ecologist's preference of "wilderness". The analyses of visual perceptions reveal the preference of semi-open woods with poor undergrowth and an inviting herb layer, over "untidy", unmanaged, with dense undergrowth and a large quantity of woody debris ([15] A. Bobiec, unpublished material). On average, the public appreciates "diverse" forests, regarding species composition, tree size and age [16,17], as well as forests offering a diversity of structures, colours, and services [18]. The human perception of a forest is positively influenced by its penetrability amplifying the visitors' aesthetic impressions and their sense of security. The latter is sometimes explained by the "savannah theory" of evolutionary psychology, according to which humanity's primeval habitat of African savannah had been encoded in our mindset. Mirroring the friendly, fertile, and relatively safe environment of savannah, semi-open woodlands are commonly favoured also by contemporary societies [19-21].

In Poland, the post-war expansion of Upper Silesia's industrial conurbation was accompanied with the development of the "protective forest belt", based on specific forestry rules, securing the best possible resistance and resilience of forests in critically unfavourable tree living conditions related to very high levels of soot, dust, and gases pollution. In general, however, unlike inhabitants of a few cities with high forest cover, such as Katowice, SW Poland (39\% of wooded area) or Sopot on the Baltic seaside (54\%), inhabitants of most of the large towns and cities suffer from the deficit of the wooded green infrastructure [22]. One of such a young, dynamically developing metropolises, is Rzeszów, SE Poland. Although the old town dates back to the 1400s, only in the aftermath of World War II has it begun its fast growth both in area and population. Between 1944 and 2021, the town expanded from a mere $8 \mathrm{~km}^{2}$ to almost $129 \mathrm{~km}^{2}$ in 2021, incorporating over a dozen nearby villages. At the same time, its population has grown from 27,000 to 198,000 in 2021, being 
abundantly fed by the immigration from the agricultural neighbourhoods [23]. During the last quarter-century, the administrative incorporation of the neighbouring villages was preempted by a spontaneous process of agricultural abandonment and suburbanization [24]. The successive annexation of rural areas to Rzeszów has not significantly increased its forest cover index. Today, it is very small and amounts to only $2.9 \%$ of the metropolitan land base [22] and the wooded areas mainly consist of small forest patches in the foothills recently incorporated into Rzeszów.

Our study was focused on a relatively small (8 ha) "Lisia Góra" dense forest reserve, perhaps the most popular piece of the green infrastructure close to Reszów's centre. The principal reserve's objective has been the conservation of the "oaks' old-growth", commonly considered as a "remnant" of an "ancient forest" [25]. Considering the ecological present and past of the reserve, we wonder whether the applied form of protection leads to its intended purpose. In order to answer that question, we perform the dendroecological reconstruction of the history of the protected "oaks' old-growth", enabling us to follow the stand's development in a spatially explicit manner. The ecological processes influencing the dynamics of the Lisia Góra ecosystem and the long-term trends of its development's trajectory are implied from the geobotanical data, in particular, from the stand composition and structure, tree regeneration, and the ground vegetation characteristics. This is considered in the context of the 250-years history of the local landscape, implied from the historic topographic maps.

Alongside the ecological study, we performed scheduled interviews with the summer visitors to the recreation area of the immediate neighbourhood of Lisia Góra. They expressed their preferences with regard to the present and alternative conservation/ management regimes as well as to the resulting landscape characteristics. We were particularly interested in how their perception of the present situation of the reserve would correspond with its present and potential future ecological characteristics.

We hypothesize that the dendroecological evidence will confirm the cartographic data, implying the non-forest past of Lisia Góra [25]. If this turned true, the oldest reserve's oaks would be the remnants of a non-forest "oakscape" (sensu [26]), a typical wooded fabric of historic traditional farmland, the most valuable and the most vulnerable component of the reserve. Based on the empirical data from the ecological reserve's assessment and from the interview, we conclude with a conceptual comparison of three alternative management scenarios with regard to their benefits and costs.

We believe that our findings referring to the Lisia Góra case may provide a valuable contribution to the broader discourse on the role and meaning of urban forests in an increasingly urban global community. We suggest that urban forests should be considered an important "medium" with a mission of developing people's responsibility for the bio-cultural heritage of wooded rural landscapes.

\section{Materials and Methods}

\subsection{Study Area}

The study's focus area (Figure 1) is a relatively small (8 ha), dense woodland, "Lisia Góra" (meaning in English "fox mount", N 50.010 , E 21.989 ). Despite the fact that nonforest, agricultural land use (plough-fields and grassland) lasted until the mid-1800s (as documented on the first and second Habsburg Military maps-Arcanum, https:/ / maps. arcanum.com, accessed on: 28 August 2021, Figure 1), Lisia Góra is commonly considered (as read in tourist pamphlets and local media) as a relic of the "ancient forest". It is located mainly on the plateau developed on the Pleistocene upper terrace covered with loess [27] (ca. $210 \mathrm{~m}$ a.s.l.) cut by a steep scarp falling ca. $12 \mathrm{~m}$ down to the lower terrace and the left-side of the Wisłok floodplain - the most intensively used recreation area in close proximity to the city centre [28,29]. The most conspicuous Lisia Gora characteristic is the old stand of common oaks Quercus robur L. In 1998, it was designated a forest nature reserve, aimed at the conservation of the oak "old-growth". Regarding the conservation regime, during the last twenty-five years, there was apparently no major intervention into 
natural processes except for the occasional felling of single trees near the only public road and tourist paths for safety reasons. Except for a modest tourist infrastructure (such as wooden barriers along the scarp, benches, and a few educational boards), with the dense undergrowth and fallen dead trees, the wood has a "wild" look.
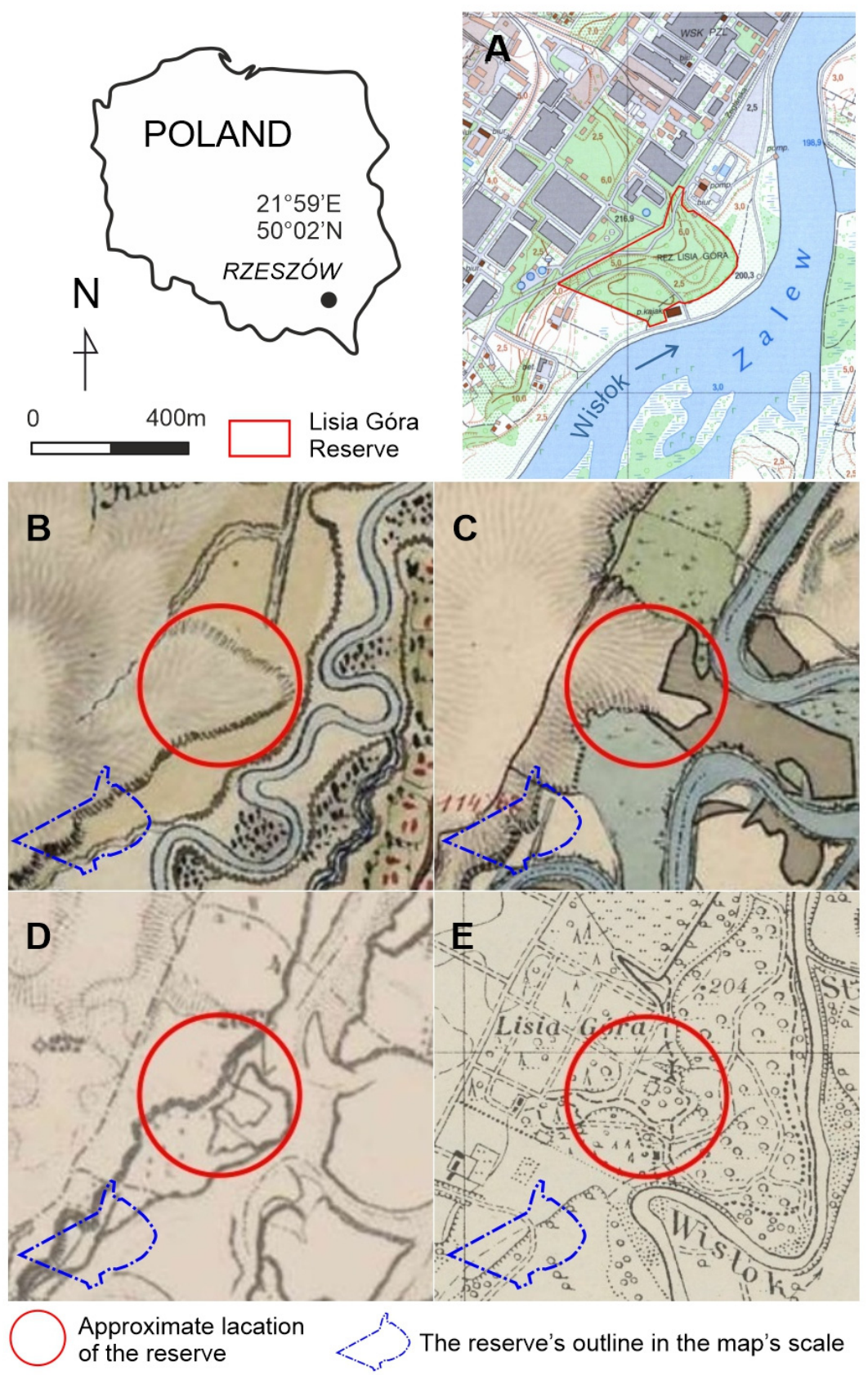

Figure 1. The study area: (A) — present topography of the reserve's location; (B)—reserve's approximate surroundings according to First Military Survey (1779-1783), western part of the map-plough field, neighbouring to the east with grassland and wetlands, little patch of riparian forest in SE; (C)—Second MS (1842-1853), NW of the square—plough field, CE—riparian woods, SW—grassland with single trees; (D)—Third MS (1869-1887), NW—arable land, SE-pasture and woodland; (E) - Polish Military Map (1938) compartmentalized park and woodland; Maps provided by Main Office for Geodesy and Cartography, Poland (A), Arcanum, https:/ / maps.arcanum.com/, accessed on 28 August 2021 (B-D), and Mapsters, http:/ /igrek.amzp.pl/mapindex.php?cat=WIG25, accessed on 28 August 2021 (E). 


\subsection{Stand Inventory and Dendroecological Reconstruction of Oak Stand History}

In winter 2018/2019, we performed the complete, spatially explicit, survey of the Lisia Góra reserve's oaks. All oaks, including downed logs, snags, and stumps, as well as other trees, which they interacted with through overlapping crowns, were mapped with the Field-Map set (IFER $\odot$, www.field-map.com, accessed on 28 August 2021). The recorded attributes of trees included species, DBH, height, crown length, and health/quality in six-point scale (1-healthy, no signs of decay; 2-present signs of decay, such as partial defoliation, bracket fungi, larger dead boughs, rot, etc.; 3-tree decadence symptoms; 4-standing dead tree, snag; 5-tall stump; 6-short, post-felling, snag). Based on the measured biometric parameters of oaks, we calculated the values of a synthetic "tree branching" index, $T b=P \frac{L c}{H}$, where $P$ is the area of the tree crown vertical projection, $L c$ - the crown's length, and H-the tree's height. In order to delineate the spatially explicit assemblages of oaks, corresponding with the following three Lisia Góra geomorphological forms: the plateau, scarp, and floodplain, we applied the alpha shapes algorithm (threshold 0.5 , no hole) in QGIS.

The reconstruction of tree recruitment was based on the determination of the calendar years in which particular oaks reached the height of $1.3 \mathrm{~m}$, the assumed baseline of saplings' recruitment into the tree layer [30]. In order to secure the highest sampling efficiency, we arbitrarily selected fifty living, 1-2 health status oaks, representing the whole range of DBH. In addition, we sampled nine dead (both standing and down) oaks and extracted wood discs from seven stumps. In the latter case of wood discs $0.2 \mathrm{~m}$ above the ground level, recruitment points were assumed four years later than the stumps' "pith years" [30]. The wood cores were glued to wooden slats, polished with 600-p sandpaper, and the rings were measured with the LINTAB- 5 device. The dead tree samples were cross dated with the chronology calculated from the live trees' series. The best matches were found with the manual cross-dating procedure (TSAP-Win v. 4.65 software, 2002-2010 Frank Rinn, RINNTECH, Heidelberg, Germany). Positions of dead tree series were determined by the best matches, according to the highest Cross-Date Index values and the Glk significance [31]. When samples were missing the pith, a "pith-finder" was used to estimate the gap's length and to calculate the number of missing oldest rings [32]. The samples that failed dating and such with more than 15 missing innermost rings were rejected. Based on the standard oaks' age and DBH data, the best fitting correlation model was found, which we used to estimate the recruitment years for the entire oak population of Lisia Góra.

\subsection{Tree Regeneration}

The whole reserve was divided into 36 sectors, most of them $50 \times 50$-metre blocks. Within each sector, three random sampling points were selected (random stratified sampling). Each point was a centre of a $100 \mathrm{~m}^{2}$ circular sampling plot (radius $5.6 \mathrm{~m}$ ), where the regeneration of trees was assessed in the following categories: $\mathrm{H} 1$ seedlings and short saplings $>0-50 \mathrm{~cm}$ (estimated relative plot cover in six-point Braun-Blanquet scale), H2 saplings $>50-130 \mathrm{~cm}$ (No., number of individuals), H3 > 130-250 cm (No.); H4 > $250 \mathrm{~cm}$ (No.).

\subsection{Floristic Survey}

In order to determine the geobotanical status of Lisia Góra vegetation in the context of the conservation regime, the reserve's vascular plants flora was subject to the total survey in 2011-2016 (Table S1). Following "Atlas of vascular plants of Poland" [33], we assigned to species the following C. Raunkiaer's life forms: phanerophyte (Ph), chamaephyte (Ch), hemicryptophyte $(\mathrm{H})$, geophyte $(\mathrm{G})$, therophyte $(\mathrm{T})$, and hydrophyte $(\mathrm{Hy})$. The origin of species (whether native or alien) was determined on the basis of "Alien species in Poland" [34]. A species was considered either "native" or "alien" (with the distinction of invasive species). We also ascribed to ecological groups, i.e., their typical affinities to habitat types [35]: forest, meadow and grassland, water and marsh, and ruderal species. In addition, following Dzwonko and Loster [36], we specified which species belong to the "ancient forest species" category. As the dispersal mode and velocity play a crucial role 
in plants' colonization, they were considered as important features of species' life strategies [37]. For the reference, we used the analogous data from two studies characterising the well-developed communities in the same region. For oak-hornbeam forest, we used Las Ratośniówki, ca. $20 \mathrm{~km} \mathrm{SW}$ from Lisia Góra, referred already in the 19th century as a dense deciduous forest [38], and for the riparian-mixed forest- - the Góra Chełm forest reserve (33 km SE) (T. Wójcik and M. Ziaja, unpublished data).

\subsection{Interviews with People}

In summer 2017, 260 field interviews with visitors/people passing-by were conducted either in front of the Lisia Góra reserve (most of them) or inside the reserve. The interviewees were asked about their preferences regarding the way the reserve should be managed/protected: whether as a nature reserve with access restrictions or open landscape with visible topography and groups of trees or dense forest or recreation area with leisure infrastructure. Each option was assessed by the interviewees as either positive, negative, or neutral (Form S1). In addition, they were also asked to select their favourite pair of synthetic drawings, one representing the view from the river toward Lisia Góra and the other one- the lookout from Lisia Góra toward the river, illustrating the following four alternative scenarios of the reserve use/management:
A. Lisia Góra as a dense forest
B. Lisia Góra as a semi-open landscape with solitary trees and small groves
C. Lisia Góra as the backyard of a residential area
D. Lisia Góra as a recreation park with leisure infrastructure

(See Form S1).

\section{Results}

\subsection{Oak Stand Characteristics}

The overall oak population of Lisia Góra consisted of 332 oaks, including 27 dead trees (17 snags and 10 down) and 22 short stumps. Among the 283 living oaks, symptoms of crown decline (dying and dead branches) were noticed in 36\%, with $5 \%$ of the oaks being in severe decline. We identified three separate, oak-dominated assemblages corresponding with three distinct geomorphological forms, i.e., the plateau assemblage, occupying 1.88 hectares (on average, 65 oaks per hectare); the steep scarp, 1.99 ha $\left(50 \mathrm{ha}^{-1}\right)$; and the flat bottom, a part of the former Wisłok river's flood-plain, $0.82 \mathrm{ha}\left(101 \mathrm{ha}^{-1}\right)$. The remaining $42 \%$ of the reserve is occupied by the young stand, dominated by sycamore maple Acer pseudoplatanus L. (Figure 2).

Besides the oaks themselves, the species interacting with Q. robur trees were (in descending order) field maple Acer campestre L., sycamore maple Acer pesudoplatanus L., common hornbeam Carpinus betulus L., elm Ulmus sp., small-leaved linden Tilia cordata Mill., common ash Fraxinus excelsior L., ash-leaved maple Acer negundo L., black locust Robinia pseudoaccacia L., norway maple Acer platanoides L., common beech Fagus sylvatica L., scots pine Pinus sylvestris L., white poplar Populus alba L., and aspen Populus tremula L.

The unimodal, right-skewed frequency distribution of the whole reserve's population of oaks (including snags, $n=315$ ) in DBH classes implies a recent, relatively intense, whether natural or man-driven, regeneration "wave", preceded by a long-lasting and rather continuous regeneration (Figure 3). However, more detailed evidence on the oaks stand history is provided by the frequency of recruitment years detected from the tree ring data. Although the oldest sampled oak reached its height of $1.3 \mathrm{~m}$ in 1841 (complete tree ring series, including pith), there may be a few more of a similar age or even older; due to the extensive internal rot, their reliable dating was not possible. With 52 qualified wood series used for the stand dendroecological reconstruction, two distinct recruitment waves were revealed. The longer one extended from 1880 to 1910 and the shorter one from 1940 to 1960 . However, single oaks used to emerge in the early 1800s, as some did by the end of 1970s (Figure 4). 


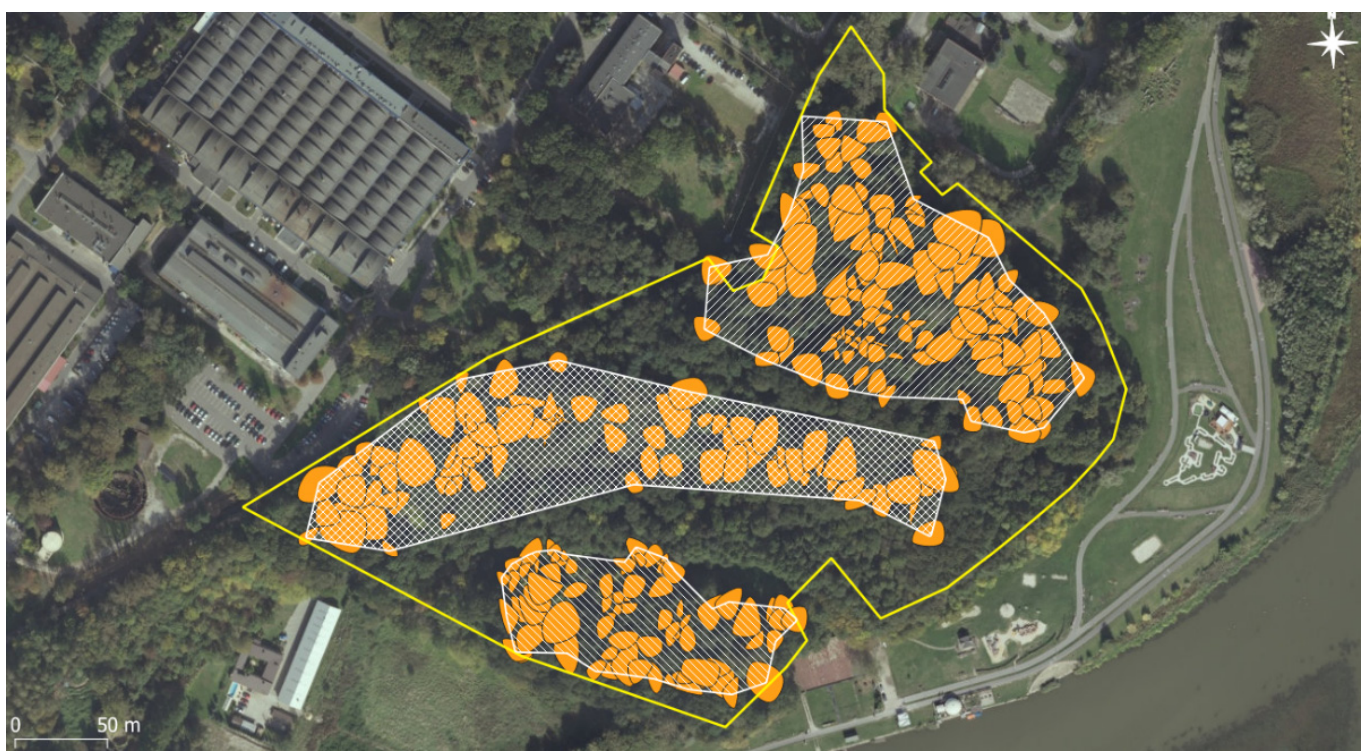

Figure 2. Three distinct assemblages of oaks: on the top-post-arable plateau; in the middle—steep scarp; in the bottom-part of the former floodplain terrace.

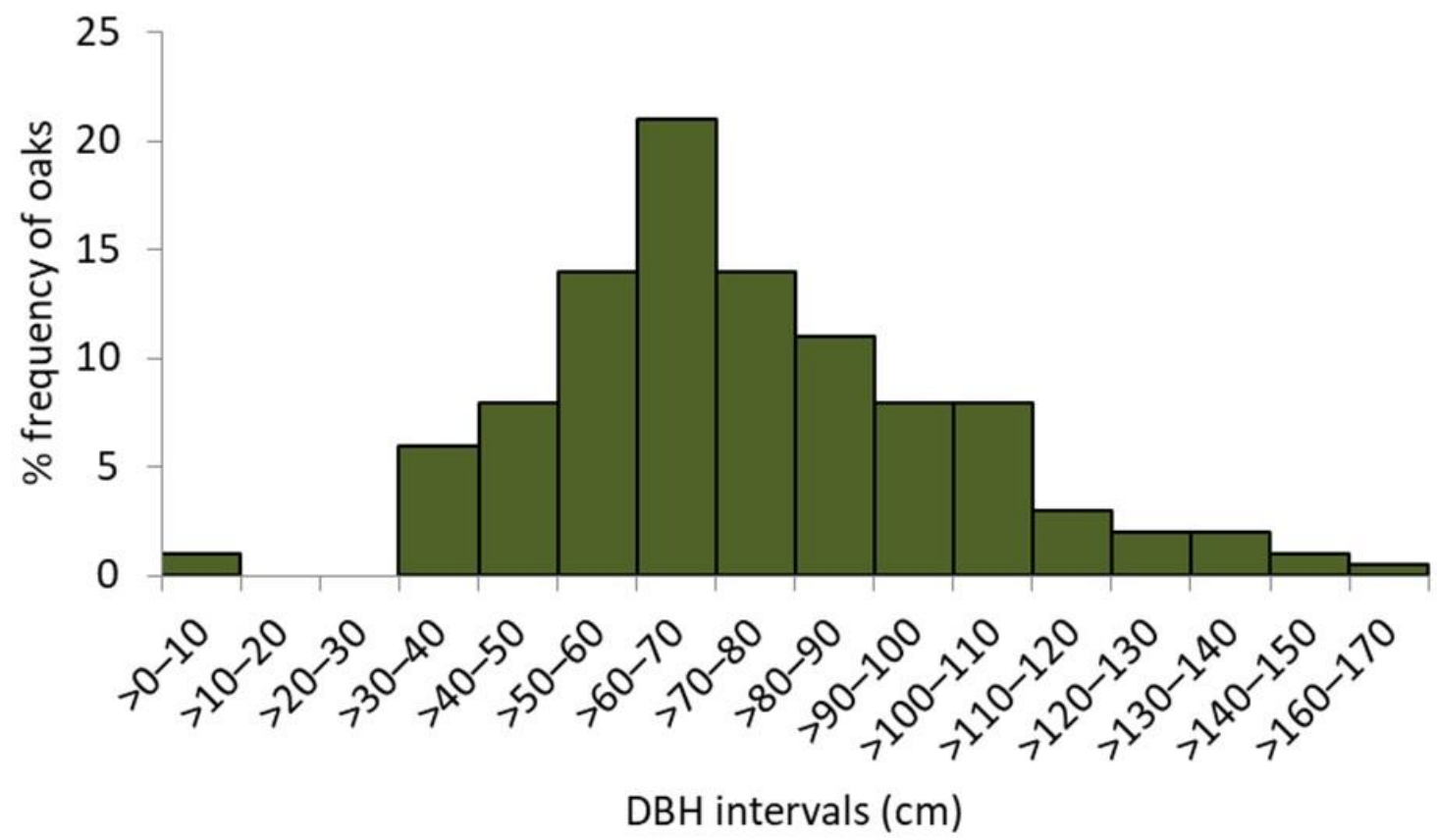

Figure 3. The relative frequency distribution of oaks in 10-centimeter diameter (DBH) classes; $n=325$.

With regard to the differences between the three oaks assemblages, the one occupying the floodplain terrace was significantly younger (mean recruitment year 1913) than the plateau (1902, Tukey post hoc pairwise test, $p=0.001)$ and scarp $(1898, p=0.000)$ assemblages (Figure 5A). The analogous comparison of the tree branching index mean values revealed that the scarp's assemblage had a significantly higher portion of the widespreading crown oaks (mean $\mathrm{Tb}=104.3$ ) than in the floodplain (mean $\mathrm{Tb}=73.0$, Tukey post hoc pairwise test, $p=0.005$ ) and on the plateau (mean $\mathrm{Tb}=73.0, p=0.013$ ) (Figure 5B). 


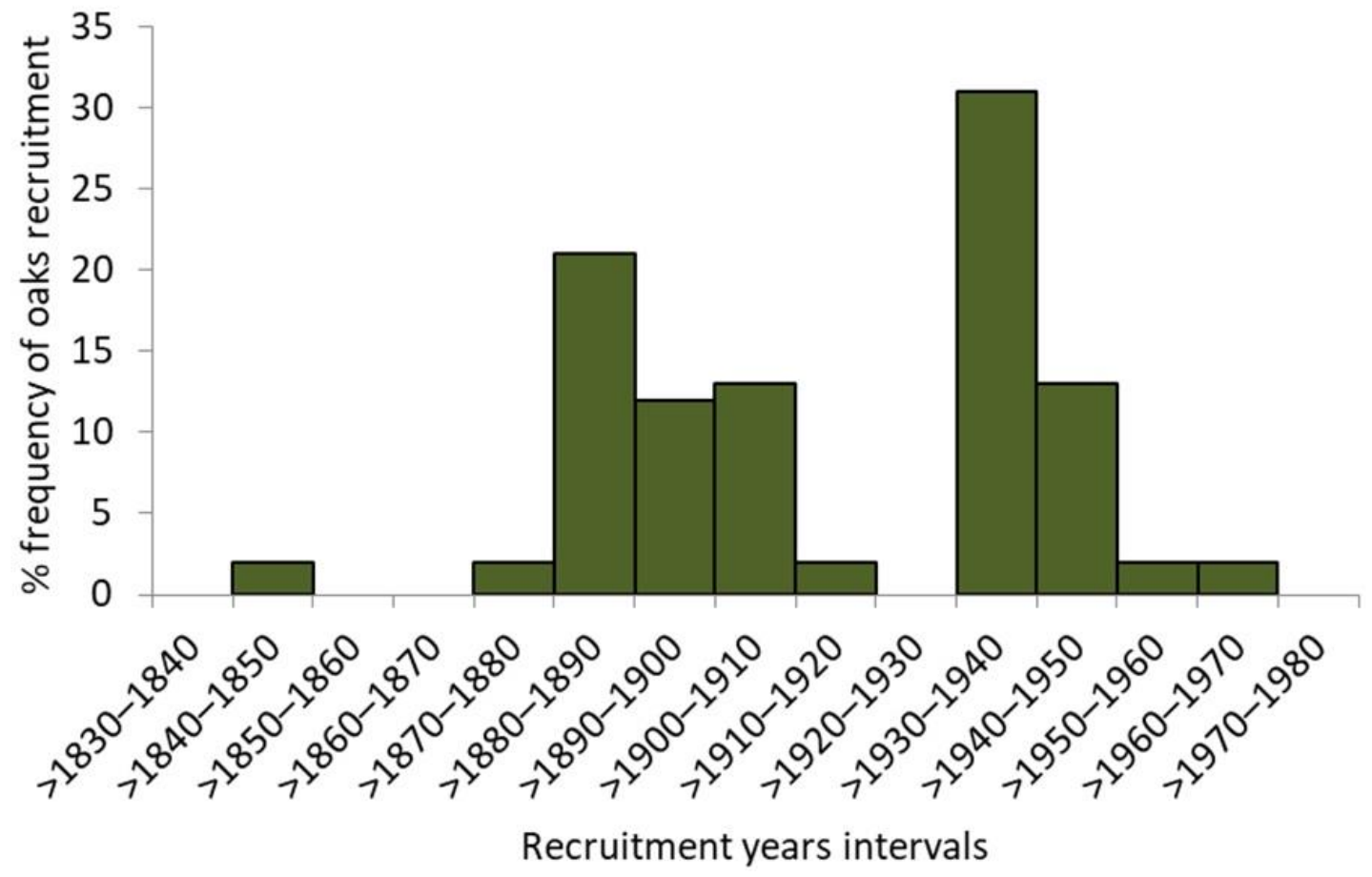

Figure 4. The relative frequency of oaks recruitment in ten-year intervals based on the reconstruction using 52 wood ring series.
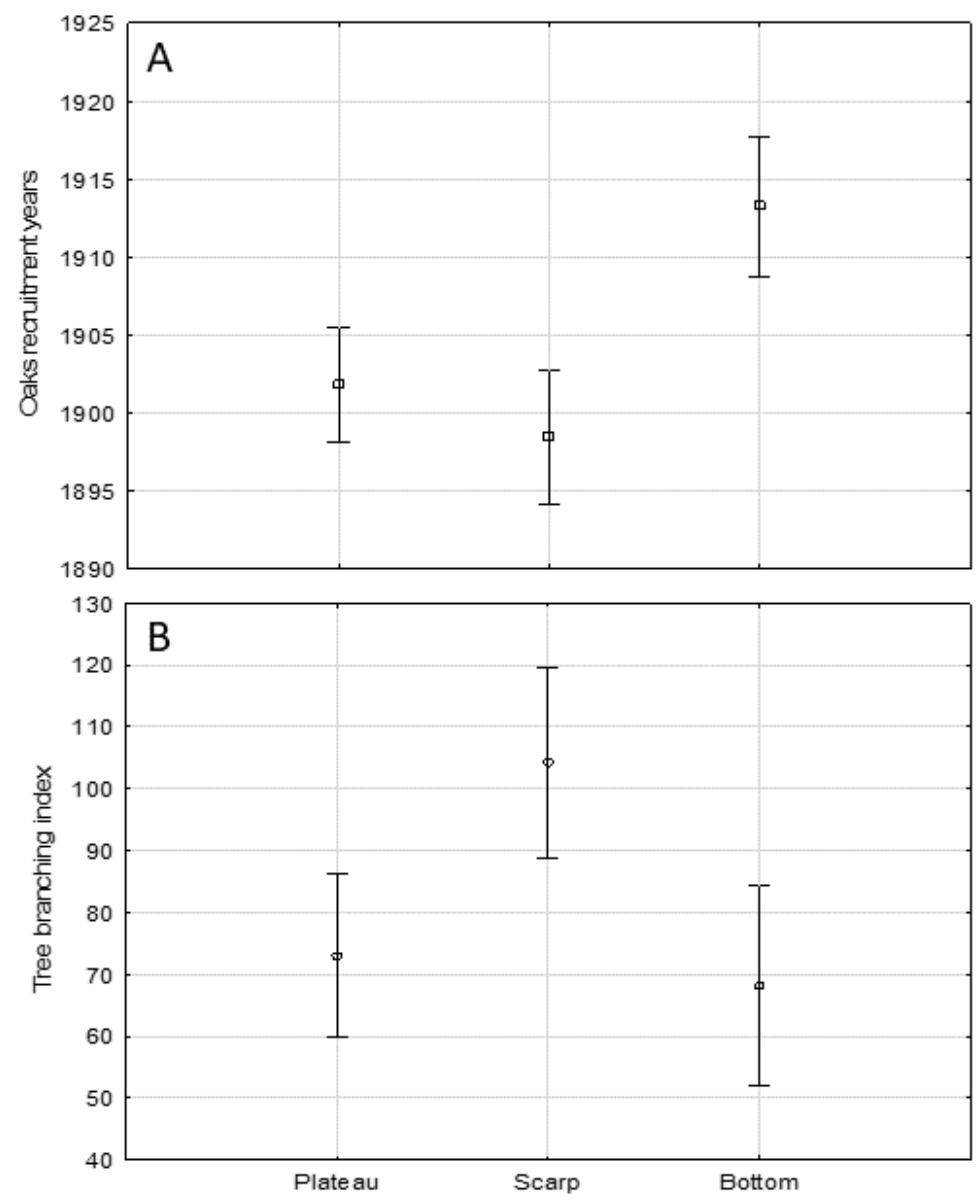

Figure 5. The comparison of average oaks (A) recruitment years in three Lisia Góra geomorphological forms; means \pm 0.95-confidence level; one-way ANOVA, $\mathrm{F}(2,293)=12.126, p=0.000 ;(\mathbf{B})$ branching index values in three Lisia Góra geomorphological forms: means \pm 0.95 -confidence level; one-way ANOVA, $\mathrm{F}(2,291)=6.371, p=0.002$. 
As shown in Figure 6, the oaks recruited in the nineteenth century are substantially more widely branched than their younger counterparts.

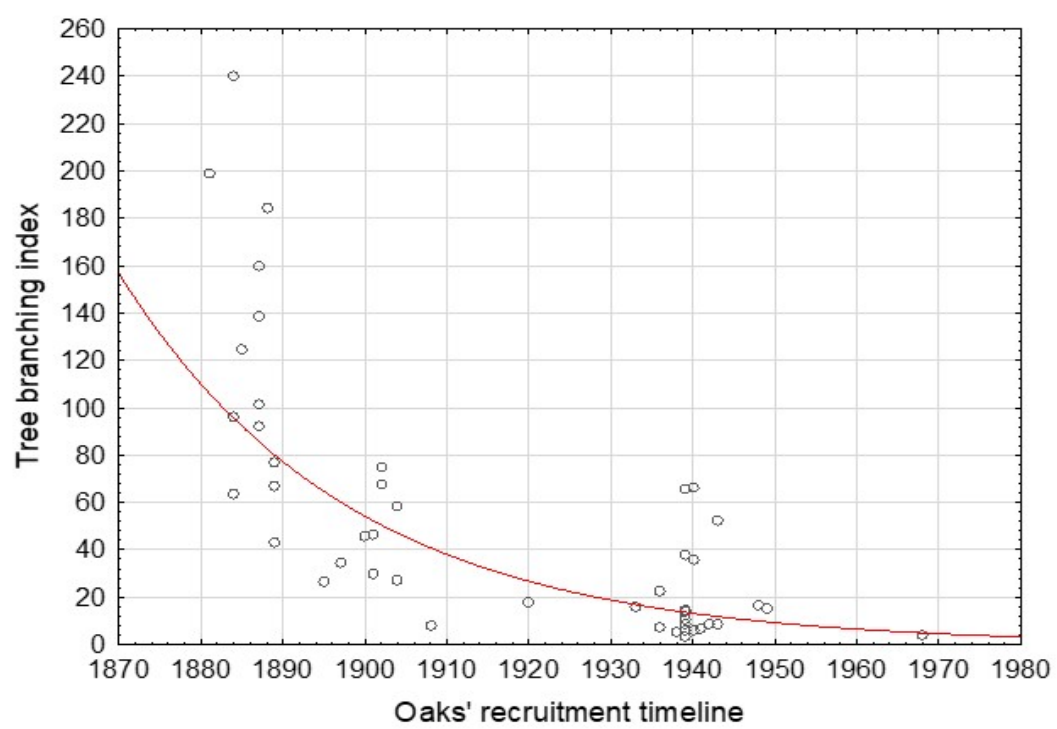

Figure 6. Exponentially decreasing oaks' tree branching index based on the data from 46 cored oaks; $\mathrm{r}=-0.702$.

\subsection{Undergrowth and Tree Regeneration}

The regeneration inventory in 108 random plots revealed an overwhelming dominance of maples (in particular, sycamore maple), followed by the elm "type". Neither oak, pioneering (aspen, birch, poplar), nor alien (black locust, ash-leaved maple) species had medians higher than zero. That applied to both seedlings with short saplings $(\leq 0.5 \mathrm{~m}$, the abundance evaluated as a \% of a plot's area occupied by a species; Friedman's rank test, Chi-square Friedman $=0.000)$ and taller saplings $(>0.5-5 \mathrm{~m}$, counts of sapling individuals on the plots, Chi-square Friedman $=0.000$ ) (Figure 7A,B). With regard to shrub species, the undergrowth was overwhelmingly dominated by bird cherry Padus avium Mill. and black elder Sambucus nigra L., each with a median $15 \%$ of the plots' cover (Chi-square Friedman $=0.000$ ) (Figure $7 \mathrm{C}$ ), contributing, together with the tree canopy layer, to very poor light conditions on the ground level.

\subsection{Ground Vegetation}

The reserve's flora consists of 215 species of vascular plants (including 24 non-native): 147 (almost 20\% alien) species in the "oak-hornbeam-like" forest, occupying the scarp and the plateau, and 173 (11\% alien) in the "riparian-mixed" forest in the lower terrace. Whereas hemicryptophytes and phanerophytes were the dominating life forms (94 and 57 species, respectively), geophytes and therophytes had similar, lower shares (Table 1). Regarding the ecological groups represented in the reserve, the forest contributed to more than half of the present species, including 45 "ancient woodland" species ( $37 \%$ of all the forest Lisia Góra species) (Table 1). The most common "ancient woodland" species were Galeobdolon luteum Hudss, Adoxa moschatellina L., Anemone nemorosa L., Circaea lutetiana L., Ficaria verna Huds., Stellaria nemorum L., and Pulmonaria obscura Dumort (for the complete floristic data see Table S1). 

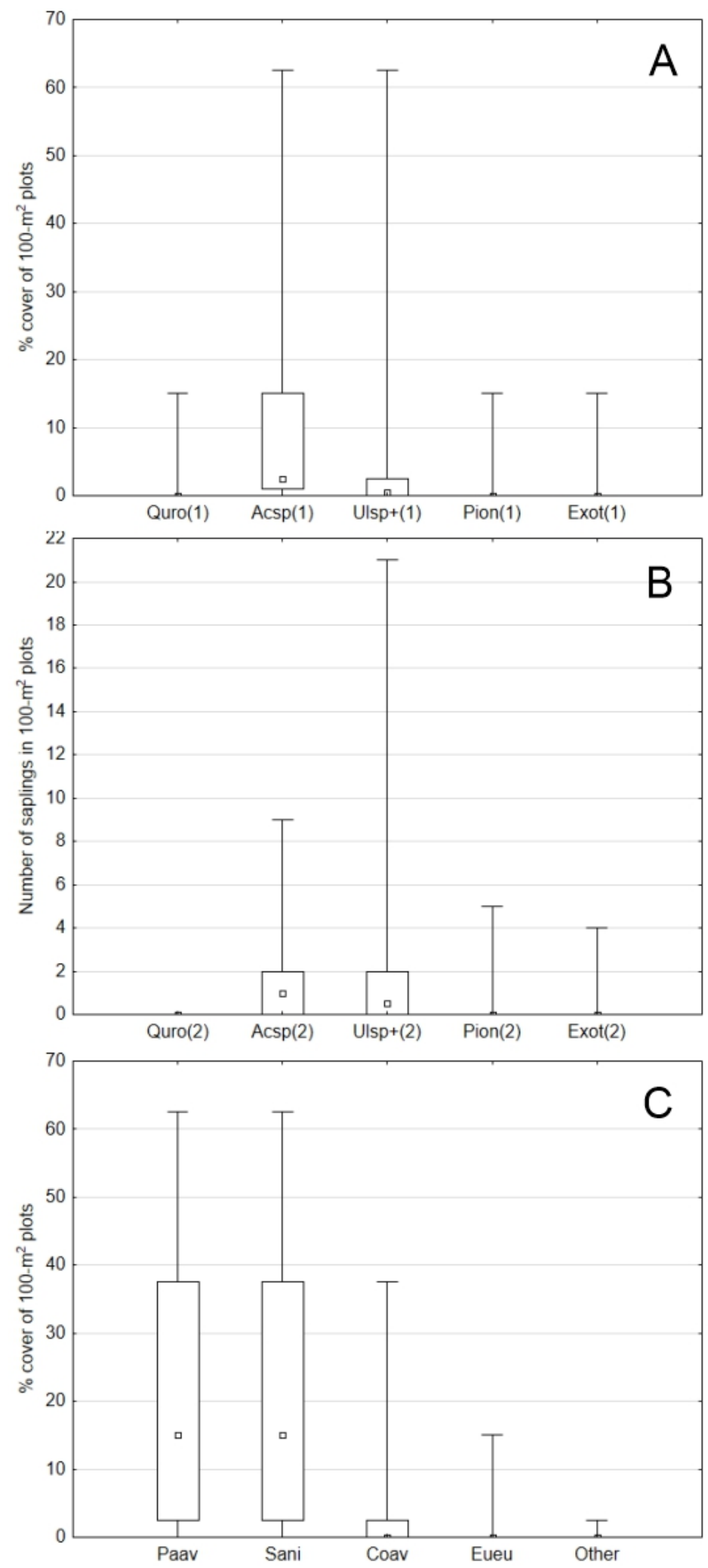

Figure 7. Undergrowth abundance (medians-interquartile range-min-max) in 108 plots (stratified random sampling); (A): seedlings and short saplings $(\leq 0.5 \mathrm{~m}),(\mathbf{B})$ : taller saplings $(>0.5-5 \mathrm{~m})$, (C): shrubs; Quro-Quercus robur, Acsp-Acer pseudoplatanus + A campestre + A. platanoides, Ulsp+Ulmus laevis and U. glabra + Carpinus betulus + Fraxinus excelsior + Fagus sylvatica, Pion-Populus alba + P. tremula + Betula sp., Exot-Robinia pseudoaccacia + Acer negundo, Paav-Padus avium, Sani-Sambucus nigra, Coav-Corylus avellana, Eueu-Euonymus europaea. 
Table 1. Selected characteristics (expressed in species numbers) of the flora of Lisia Góra (LG) reserve, represented by deciduous oak-hornbeam forest $\mathrm{LG}(\mathrm{OH})$, occupying the plateau and scarp, and riparianmixed forest LG(RM) in the floodplain part; they are compared to the reference oak-hornbeam $\mathrm{OH}$ in Ratośniówki [38] and riparian-mixed forest RM of Góra Chełm reserve (T. Wójcik and M. Ziaja, unpublished data); blue font-significant difference between LG and its reference (Chi-square goodness of fit, $p<0.05)$; brown $(p<0.05)$ and green $(0.05 \leq p<0.10)$ font-significant difference of the frequency distribution between LG and reference habitats (Chi-square independence); $\mathrm{Ph}$ - phanerophytes, $\mathrm{Ch}-$ chamaephytes, H-hemicryptophytes, G-geophytes, T-therophytes, Hy-hydrophytes, in bracktesnumber of alien invasive species; See Table S1 for the completed dataset.

\begin{tabular}{|c|c|c|c|c|c|}
\hline \multirow{2}{*}{ Species in Toto } & LG & LG(OH) & $\mathrm{OH}$ & LG(RM) & $\mathbf{R M}$ \\
\hline & 215 & 147 & 209 & 173 & 184 \\
\hline & \multicolumn{5}{|c|}{ origin } \\
\hline native & 190 & 124 & 194 & 156 & 180 \\
\hline \multirow[t]{2}{*}{ alien $\left(^{*}\right)$} & $24(13)$ & 23(13) & $15(7)$ & $17(9)$ & $4(4)$ \\
\hline & \multicolumn{5}{|c|}{ life form } \\
\hline $\mathrm{Ph}$ & 57 & 46 & 42 & 48 & 38 \\
\hline $\mathrm{Ch}$ & 7 & 6 & 13 & 5 & 10 \\
\hline $\mathrm{H}$ & 94 & 58 & 93 & 72 & 88 \\
\hline G & 29 & 17 & 39 & 24 & 39 \\
\hline $\mathrm{T}$ & 23 & 20 & 22 & 19 & 7 \\
\hline \multirow[t]{2}{*}{ Hy } & 5 & 5 & 0 & 2 & 0 \\
\hline & \multicolumn{5}{|c|}{ ecological affinity } \\
\hline forest & 109 & 86 & 117 & 87 & 121 \\
\hline meadow, grassland & 44 & 22 & 57 & 34 & 32 \\
\hline ruderal & 40 & 38 & 33 & 30 & 17 \\
\hline \multirow[t]{2}{*}{ water, marsh } & 22 & 0 & 2 & 22 & 14 \\
\hline & \multicolumn{5}{|c|}{ dispersal } \\
\hline autochory & 109 & 75 & 120 & 83 & 92 \\
\hline \multirow[t]{2}{*}{ other } & 106 & 72 & 89 & 90 & 92 \\
\hline & \multicolumn{5}{|c|}{ ancient woodland species/ other species } \\
\hline /any other & $45 / 170$ & $37 / 110$ & $65 / 144$ & $33 / 140$ & $70 / 114$ \\
\hline /other forest & $45 / 64$ & $37 / 49$ & $65 / 52$ & $33 / 54$ & $70 / 51$ \\
\hline
\end{tabular}

Compared to the reference plant communities, the Lisia Góra habitats revealed substantial differences. For instance, the oak-hornbeam forest in Ratośniówki had almost twice as many "ancient woodland" species (64 species, very abundant, major component of the herb layer biomass) as in Lisia Góra (37 species, usually scarce and scattered). Another conspicuous difference was the position of ruderal species, being less numerous in Ratośniówki (30 vs. 38 species in Lisia Góra) and spatially limited to the peripheral zone of the Ratośniówki woods, comparing to Lisia Góra, where such plants abound throughout the reserve. The contrast was even sharper for the riparian-mixed forest, with 17 ruderal species in Góra Chełm and 30 in Lisia Góra (Table 1). The geophytes flora, mostly dependent on the low-pace autochory and very characteristic for deciduous forests, was far richer in the reference habitats ( 39 species in both oak-hornbeam and riparian-mixed habitats) than in their Lisia Góra counterparts (17 and 24, respectively) (Table 1). 


\subsection{Visitors' Views on Lisia Góra Management Scenarios}

There were $45 \%$ men and 55\% women among 260 people interviewed in the Lisia Góra neighbourhood. The dominating purpose of their visits was broadly understood to be leisure and recreation (63\%), followed by sport (mainly running, biking, and skating-14\%), socializing (meeting with friends, BBQ-12\%), playing with children $(5.5 \%)$, observing nature $(3.5 \%)$, working or passing by $(2 \%)$. The overwhelming part of the interviewees were either inhabitants of Rzeszów city (80\%) or Rzeszów county $(14 \%)$.

Regarding the descriptive characteristics of the reserve's conservation/management system, the visitors' most favourable scenario was the "open landscape with visible topography and groups of notable trees" $(72 \%)$, before the "dense forest following the course of nature" (51\%). On the other side of the spectrum, the options of "nature reserve with access legal restrictions" and "area of mass recreation" were most frequently disliked, by 48 and $41 \%$ of the interviewed visitors, respectively (Table 2 ).

Table 2. The visitors' (inclusive) preferences with regard to Lisia Góra conservation/management descriptive scenarios and possible accessibility solutions. NR-nature reserve, OL-(semi)open landscape, DF-dense forest following natural dynamics, RA - recreation area; asterisks in different columns indicate significantly differing proportions, Chi-square for independence, $p<0.05$.

\begin{tabular}{|c|c|c|c|c|c|}
\hline \multirow{2}{*}{ Way of Management } & \multirow[t]{2}{*}{ Symbol } & \multicolumn{3}{|c|}{ Interviewees' Evaluation } & Independence \\
\hline & & Positive & Negative & Neutral & \\
\hline $\begin{array}{l}\text { Nature reserve with } \\
\text { legal access restrictions }\end{array}$ & NR & 31 & 48 & 21 & * \\
\hline $\begin{array}{l}\text { Open landscape with visible } \\
\text { topography and groups } \\
\text { of notable trees }\end{array}$ & OL & 72 & 12 & 16 & * \\
\hline $\begin{array}{l}\text { Dense forest following the } \\
\text { course of nature }\end{array}$ & DF & 51 & 23 & 26 & * \\
\hline $\begin{array}{l}\text { Area of mass recreation } \\
\text { (playground, rope park, } \\
\text { toboggan run, etc.) }\end{array}$ & RA & 42 & 41 & 17 & * \\
\hline
\end{tabular}

The demonstrated preference of "Open landscape with visible topography and groups of notable trees" (Table 2) was confirmed by the most frequent selection of its graphic visualisation ( $44 \%$ vs. $26 \%$ opting for the next most favourite scenario of a leisure park). However, the pairwise correspondence of the graphic-based selections and the analogous descriptive scenarios' definitions (Table 2), except the pair of the illustrations of the "wild forest" and the nature reserve (NR), were poor and ambiguous (Figure 8). 

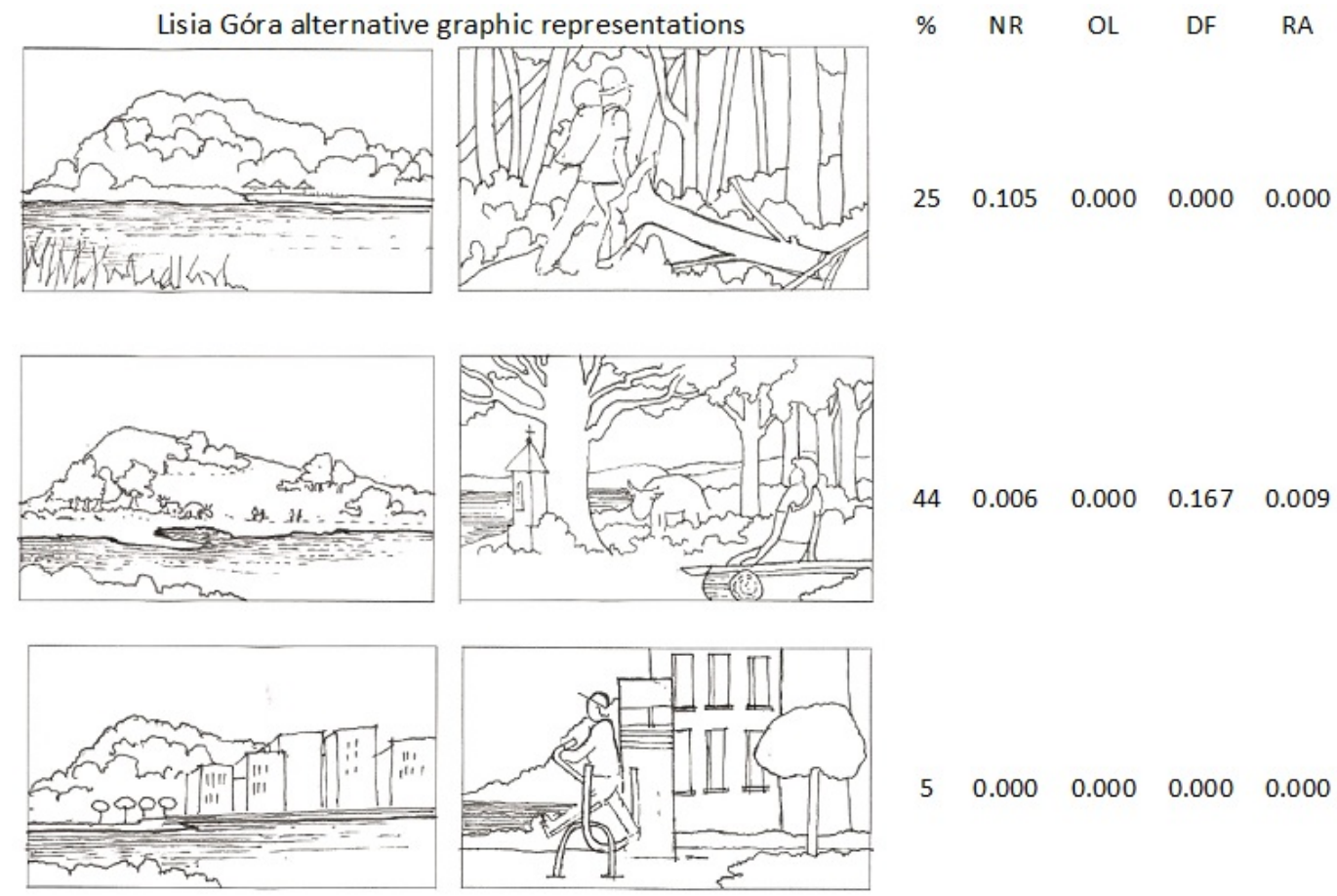

$\begin{array}{lllll}5 & 0.000 & 0.000 & 0.000 & 0.000\end{array}$
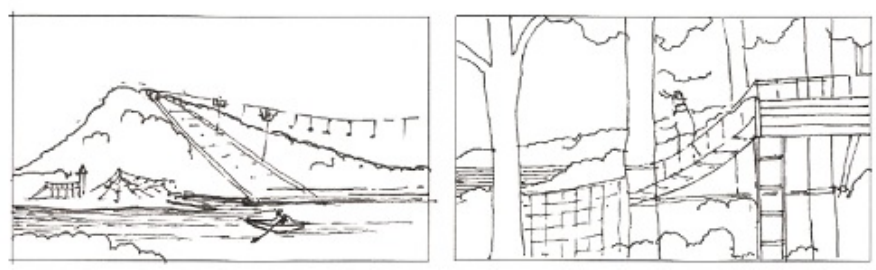

$\begin{array}{lllll}26 & 0.178 & 0.000 & 0.000 & 0.000\end{array}$

Figure 8. Relative distribution of the visitors' (exclusive) percent preferences (\%) referring to four alternative graphic representations of Lisia Góra; in four columns on the right: $p$ values in Cochran $Q$ test for differences between the preferences of visual and descriptive reserve's scenarios; for NR, OL, DF, RA explanation see Table 2.

\section{Discussion}

Although we did not perform the dendrochronological analysis of other tree species occurring in Lisia Góra reserve, only a few beech and ash individuals might have reached the age of 100 years. All three geomorphological forms of the reserve, i.e., the plateau, the scarp, and the flood-plain terrace are "grated" with the fabrics of separate common oak stands (Figure 2). Both their spatial structure and age imply an asynchronous and spatially heterogeneous recruitment. This corresponds with the available historic maps. Although the cartographic techniques used in the First Military Survey do not allow us to achieve a higher georeferencing accuracy than $100 \mathrm{~m}$ [39], the late 1700s' map of Lisia Góra's surroundings depicts a typical agricultural landscape, with plough fields dominating the plateau, grasslands extending throughout the scarp and the lower terrace, and the only forest patches scattered throughout the floodplain in the vicinity of the river channel. This is confirmed by the following two, more accurate military surveys (the Second and the Third, mid- and the second half of the 19th century), symbolically notifying the presence of sparse trees in grasslands (Figure 1). Some of them may still be surviving in the scarp's assemblage, where there are several short-stemmed and wide-branching old oaks (Figures 2, 5, 6 and 9). 


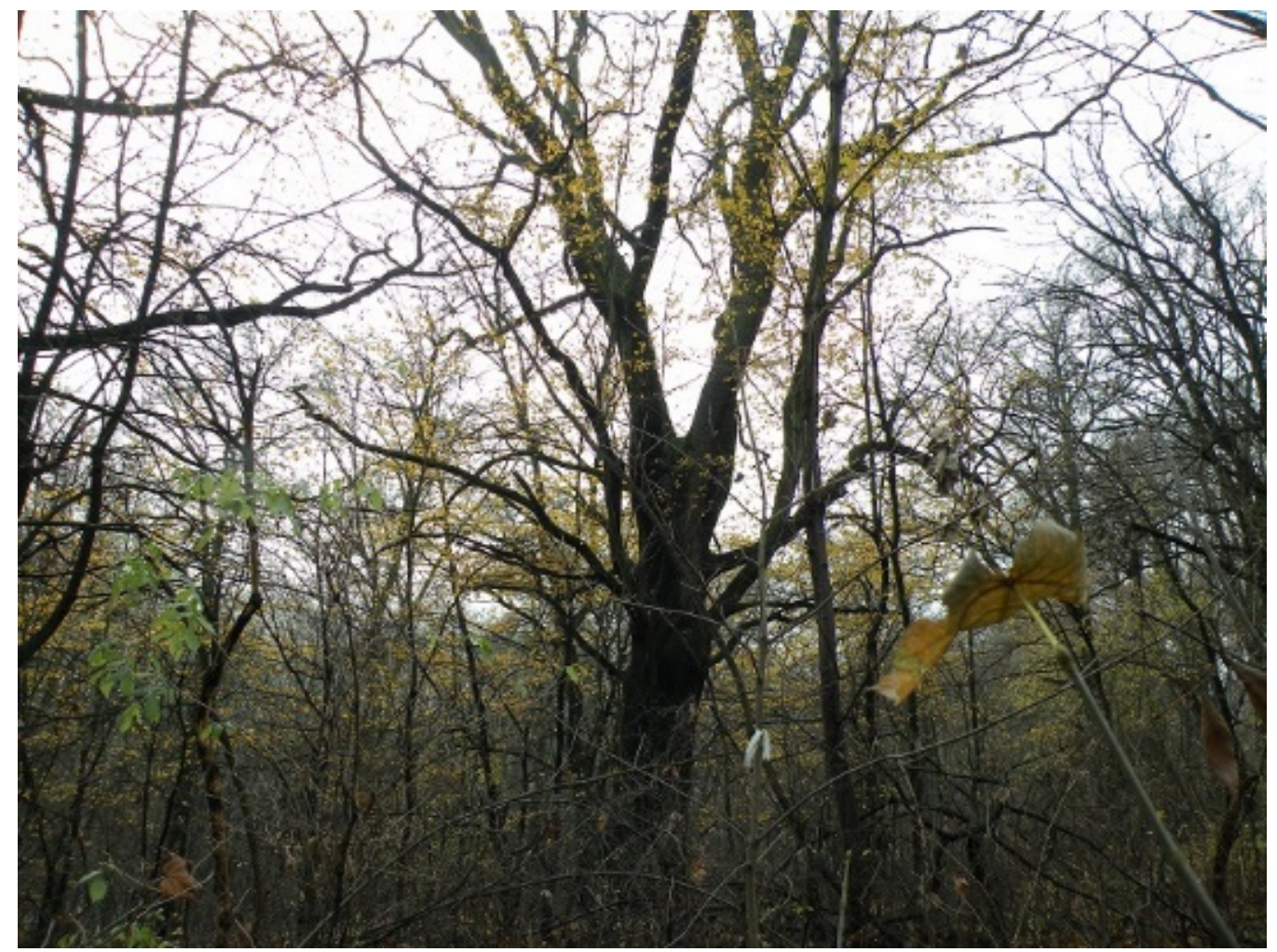

Figure 9. A "shadow" scarp's treed grassland: the open-grown oak on the Lisia Góra scarp; the tree's branching index $\mathrm{Tb}=301$ (comparing to $\mu=81.233, \sigma=75.416, n=294$ ).

The first wave of oaks' recruitment, identified by the dendroecological reconstruction, occurred between 1880 and 1910 (Figure 4), mainly on the plateau verge and the scarp. Although we did not find any "hard" evidence, it might have been triggered by the abandonment of the agricultural use of Lisia Góra, providing the conditions favouring spontaneous oak regeneration [26]. According to the 1920s' project of the "English park", which would largely overlap Lisia Góra, almost 2500 trees (oaks and other species) were to be planted on the plateau and the lowest terrace [40]. The project's implementation coincides with the second (and the last) regeneration wave, narrower and more intense than the previous one, lasting from 1930 to 1950 (Figure 4). The afforestation campaign has a plausible additional footprint in the oaks' $\mathrm{DBH}$ structure, with the highest oaks frequency in the $>60-70 \mathrm{~cm}$ interval (Figure 3). Interestingly, shortly before World War II, the oldest (then ca. 160-years-old) stand of Lisia Gora (on the verge of the plateau and on the scarp) was considered for protection as a "nature reserve" [41,42]. The map of 1938 (Figure 1E) depicts regular alleys and forest cover, indicating that a park design had been realized. However, according to the topographic map of 1967, Lisia Góra was then already a compact block of woodland. We suppose that neglecting the park maintenance in the war aftermath has allowed succession processes to develop a broadleaf forest, assigned in 1998 the status of forest reserve aimed to protect the "oak old-growth".

Although we have no data indicating that alongside oaks and a few pines other species were also planted, that would be a highly plausible assumption. However, fifty years after the last light demanding oaks (Ellenberg's ecological light indicator for undergrowth oaks $\mathrm{L}=7$ ) had recruited inside the reserve, its area has been entirely filled-in by several shadetolerant species, in particular, maples (mainly sycamore $\mathrm{L}=4$ ), elms (Ulmus glabra and U. laevis, $\mathrm{L}=4)$, and hornbeam $(\mathrm{L}=4)$ [43]. As the results of the undergrowth inventory show (Figure 7), the position of the shade-tolerant species will continue to grow even stronger throughout the reserve, due to the sapling bank of those species, alongside propagation by black elder and bird cherry. 
Most of the oaks emerged from the alleged afforestation campaigns, representing a typical "forest tree" architecture, adapted to a tough side competition against neighbouring trees. However, their open-grown, older counterparts (mostly on the scarp or on the edge of the plateau), which developed wide-spreading crowns on relatively short trunks, are very vulnerable to the increasing pressure from the younger dense stand of shade-tolerant species (Figure 9). The process of progressive weakening and dieback of older oaks in dense forests, caused by competition and pressure from shade-tolerant trees, is observed in various parts of Europe [44-46]. Although severe crown decline in Lisia Góra pertains to a mere $5 \%$ of all the living oaks, moderate symptoms of decay were observed in $30 \%$ of the population, which may anticipate a looming substantial loss of oaks in the foreseeable future. Both the DBH and age structure of the studied population (Figures 3 and 4) prove almost total regeneration and recruitment failure during the last seventy years. Despite very abundant seedlings emerging after every oak mast year (usually, every 3-5 years, the authors' unpublished observations) none have even survived as a taller sapling $(>0.5 \mathrm{~m})$, except for a few specimens at the very edge of the forest (Figure 7A,B). Even the major local disturbances caused by the collapse of large oaks, though not surprising, have not resulted in a single case of oak's recruitment. As shown in the strict nature reserve of the Białowieża National Park (an area almost 600-fold larger than Lisia Góra), only "catastrophic mode" disturbances, usually related with multiple uprooting of spruce trees Picea abies L., H. Karst., provide a conducive opportunity for successful oak regeneration [47,48]. Both "continuous mode" and "gap dynamics" regeneration depend on a species' ability to build up and sustain its "undergrowth bank", absent in the oak's life strategy [26]. Therefore, considering the small size of the reserve, lack of a stand component prone to "catastrophic" disturbances (such as spruce), and the overwhelming dominance of young shade-tolerant canopy trees and their undergrowth, there are no rational premises to assume that natural processes may sustain a noticeable number of oaks in the Lisia Góra reserve.

Although the present plant communities dominating in the reserve can be considered "forest habitats", with respect to species composition, they reveal substantial deficits and distortions of flora compared to the "model" regional counterparts, such as "GalioCarpinetum oak-hornbeam" and "riparian mixed" forests (habitats 9170 and 91F0, respectively, according to Council Directive 92/43/EEC on the conservation of natural habitats and wild fauna and flora), well represented in both commercial and protected forests of SE Poland [49-51]. Due to the reserve's spatial isolation from the potential source of the numerous species absent in the Lisia Góra forest (the nearest deciduous forest complex is $7 \mathrm{~km}$ away, across the river and the concrete city centre, c.f. [52]), achieving the state of the natural potential vegetation through natural processes is unlikely. Unlike trees and shrubs, in particular the fruit species, such as bird cherry and elder, being abundantly propagated by birds, the import of many ground vegetation species, is at best problematic. Wolański et al. [53] have shown that even sixty years after connecting silvopastoral groves with the vast ancient woodland, they still were missing numerous "ancient woodland" species, despite the lack of any isolation or ecological barrier. Although one cannot exclude the successful import of forest species diaspores with alluvial processes, the anthropogenic dispersal of further inadvertent (whether native or alien) species will continue to be a dominating driver shaping the Lisia Góra communities. Thus, we anticipate, the reserve will continue to grow into a "feral parkland", increasingly polluted by exotic species, if the present "non-intervention" conservation approach is maintained. There is nothing objectively wrong in such a scenario, but it substantially diverges from the reserve's formal purpose, i.e., the "conservation of the oak old-growth". Although the oaks will not disappear during the next few decades, their health conditions will keep deteriorating due to the competition from shade-tolerant trees that are much better adapted to dense forest conditions. Therefore, considering the present trends, in the long run, preserving a considerable population of oaks does not seem feasible. It means that the present reserve's conservation strategy fails to achieve its primary purpose, i.e., the protection of the oak old-growth. Neither will it foster the development of a complete "natural forest" 
community—an impossible mission considering the reserve's small size, ecological isolation, and high human impact.

Although numerous visitors declare their preference of a "dense forest following the course of nature", still more opt for an "open landscape with visible topography and groups of notable trees" (Table 2, Figure 8). Interestingly, according to the recent internet survey on Lisia Góra, the "non-intervention" scenario was slightly more preferred than the "semi-open wood-pasture" [25]. That difference between the findings may be a derivative of the methodological differences, such as the direct interview with visitors in the field in the present study vs. self-service survey dealt with by accidental respondents involving fewer Lisia Góra visitors. The authors argued that abstract environmental constructs might underlie biased judgements of urban communities, particularly prone to the effects of a cultural alienation from tangible nature. With the generally low level of natural knowledge, the urbanites' appreciation of nature depends either on their immediate aesthetic perception, or on an induced external narrative rather than on a true experience of human-nature interactions, translating into uncodified "traditional ecological knowledge" [25,54].

As indicated in another study [25], the commonly (and falsely) assumed baseline for the Lisia Góra reserve is an "ancient forest". With the superficial stereotypical vision of an "ancient forest" as a woodland with old trees, dense undergrowth, and large quantity of dead wood, in the coming decades, Lisia Góra, for unskilled observers, may increasingly evoke its idealistic "baseline". However, due to the reserve's, earlier discussed, insurmountable limitations and deficits, after reaching the most desired look of an "old-growth", it will inevitably be followed by the long-lasting dense stand of shade-tolerant species with disappearing "relict" oaks [44,47]. Will it make the visitors and city inhabitants feel less satisfied with the state of the reserve? Probably not. Considering the well-known psychosociological phenomenon of the "shifting baseline syndrome" [55], people will gradually get used to any following changes and unconsciously accept the recent ecosystem states as new baselines. However, as our study shows, such acceptance is not unconditional. Although none of the interviewees could see, during his/her lifetime, Lisia Góra as a treed agricultural landscape (we have not even found any description or illustration of such historical aspect of this landscape), the survey's drawings and explicit description of a potential reserve's look turned to be an effective stimulus triggering the visitors' interest in the scenario alternative to dense forest. This implies that the Lisia Góra's future is not necessarily determined by slow directional progress, dependent on the described spontaneous ecological processes, unconsciously accepted by the society deprived of a permanent "reference aspect". We suggest that the progressing shifting baseline syndrome, responsible for the habitats' creeping deterioration, could successfully be cured by adopting an intentionally corrected reference model, such as semi-opened wooded grassland, restored and sustained by a suitable management/conservation system.

Taking into account the present ecological state of the reserve, the limitations of its spontaneous development, and the history of the area, there are the following three major management/conservation options worth considering with respect to Lisia Góra: (1) minimum intervention, (2) silviculture-driven development of a desirable forest state, and (3) landscape restoration and protection. According to the UNESCO classification of protected areas, they would refer to, respectively, Ia (strict nature reserve), IV (habitat or species management area), and the combination of IV and V (restoration followed by landscape protection) protected areas categories.

\section{Conclusions}

The Lisia Góra nature reserve does not fulfil its statutory objective, which is the protection of the oak old-growth. Continuous "wilding" of the feral farmland landscape, shortly turned to the "English park", ends up in a feral wood with the increasing pressure of shade-tolerant tree species on intolerant old oaks. Without an adequate intervention, their health conditions will continue to deteriorate, and the dense undergrowth will keep preventing their reproduction. However, regarding the fact that common oak is not an 
endangered species, the city could consider a change to the reserve's objective, continuing the non-intervention policy, and the spontaneous vegetation development, regardless of the long-term consequences (following Ia IUCN category). Alternatively, the most common approach in Polish forest reserves of active stand conservation management could be applied, aimed at developing and sustaining mature "oak-hornbeam" and "riparian-mixed" forest communities, requiring substantial thinning, "regeneration cuts", and-possiblyreplanting (category IV).

However, considering the explicit visitors' preference of "semi-open landscape with notable trees" to the "dense forest" and comparing the potential of the non-economic values available with different scenarios, we suggest the combination of IV and V to be the optimal approach to Lisia Góra (Figure 10). Although a non-intervention approach seems the easiest and the cheapest, considering the local context of an affluent town, this should not be a decisive factor. We would equally be sceptical to the development and sustenance of a forest enclave dependent on silvicultural intervention, mirroring numerous forests in close vicinity to Rzeszów. Therefore, we would advise an ambitious project of the restoration of the variegated treed farmland landscape, corresponding with the Lisia Góra visitor's choice and, except the plateau, referring to the landscape's historic past, grassland with small groves and scattered solitary trees. This could be achieved by spatially and temporarily diversified treatments, such as the deforestation of larger blocks of the young sycamore stand (mainly on the plateau) and undergrowth removal, followed by the restoration of wildflower grassland as well as very careful, gradual "haloing" of selected older oaks ([56] Figure 2). Both snags and larger down logs would be left in the reserve, providing habitats for hollow and cavity-nesting birds and other vertebrates, as well as for saproxylic invertebrates and fungi. Such a "pocket" picturesque rural landscape in the middle of the metropole, besides its aesthetic and recreational appeal, due to the fine-grained mosaic structure, would become a true biodiversity "condenser" and a unique open-air lab for biology, conservation, and landscape classes. Last but not least, we suggest that such "bio-cultural refugia" (sensu [57]) should become key knowledge centres of the natural, cultural, and economic importance of the "working rural landscape", fostering urban care for the countryside. We argue that such should be the direction for Lisia Góra to follow.

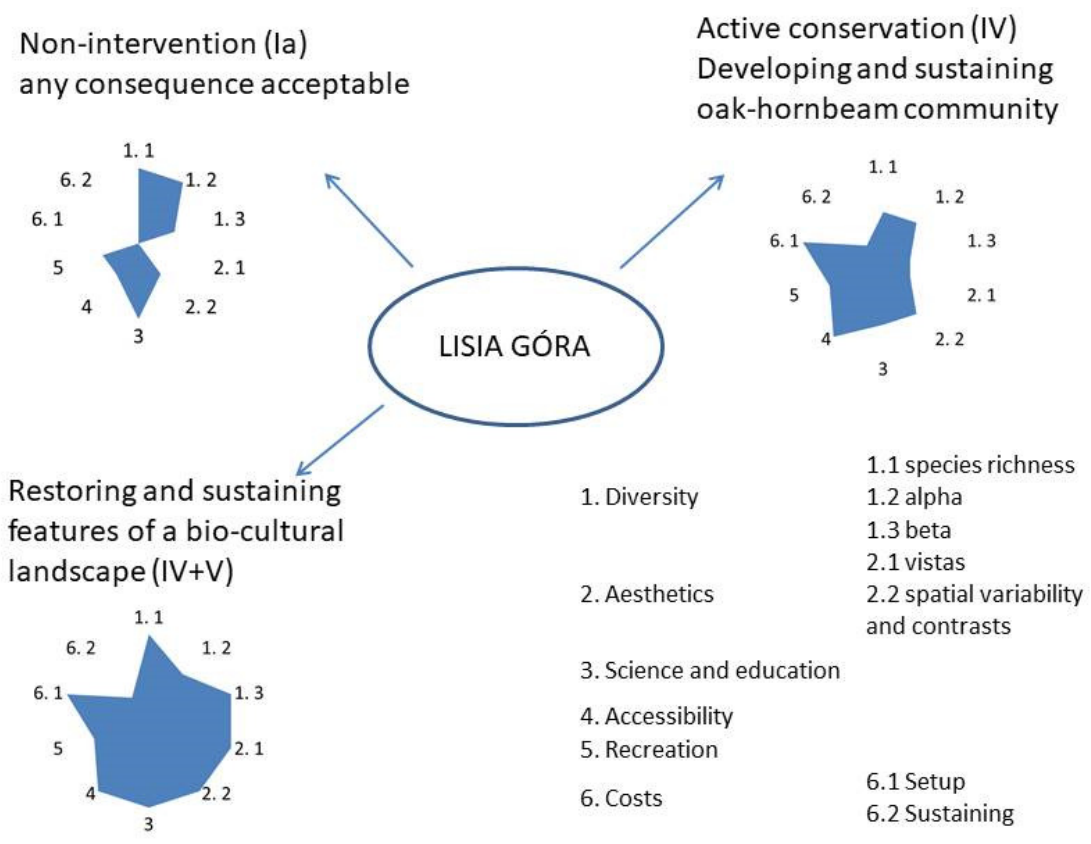

Figure 10. The relative comparison of three alternative Lisia Góra management scenarios, considering conceptual ranking of selected non-economic values and costs (relative scale from 0 to 3); symbols in brackets-IUCN categories of protected areas. 
Supplementary Materials: The following materials are available online at https:/ www.mdpi.com/ article/10.3390/f12091173/s1, Table S1: List of plant species with selected traits, Form S1: Survey questionnaire form (English translation from original Polish).

Author Contributions: Conceptualization A.B. and A.Ć.; methodology, A.B., A.Ć., A.G., T.W. and M.Z.; validation and data curation, A.B., A.Ć., A.G., T.W. and M.Z.; formal analysis, A.B.; investigation, A.B., A.Ć., A.G., T.W. and M.Z.; writing-original draft preparation, A.B.; writing-review and editing, A.B., A.Ć., A.G., T.W. and M.Z.; visualization, A.B., A.Ć. and A.G.; supervision, A.B. All authors have read and agreed to the published version of the manuscript.

Funding: This research received no external funding.

Institutional Review Board Statement: The ecological study methodology had been approved by the regional conservation authority in Rzeszów (RDOŚ Rzeszów), Decision WPN.6205.92.2015.ŁL-5 with further amendnments.

Informed Consent Statement: Not applicable.

Data Availability Statement: Data is contained within the article or supplementary material.

Acknowledgments: The authors are indebted to two anonymous reviewers for their work and invaluable comments, being a substantial contribution to the revised manuscript. The study and publication were funded through the College of Natural Sciences, University of Rzeszów.

Conflicts of Interest: The authors declare no conflict of interest.

\section{References}

1. Ritchie, H.; Roser, M. Urbanization. Our World in Data. Oxford Martin School, University of Oxford, GCDL, 2019. Available online: Worldindata.org (accessed on 12 July 2021).

2. Grebner, D.L.; Bettinger, P.; Siry, J.P.; Boston, K. Chapter 16-Urban. Forestry. Introduction to Forestry and Natural Resources, 2nd ed.; Academic Press: Cambridge, MA, USA; Elsevier Inc.: Amsterdam, The Netherlands, 2021; pp. 387-407. [CrossRef]

3. Brito, V.V.; Borelli, S. Urban food forestry and its role to increase food security: A Brazilian overview and its potentialities. Urban For. Urban Green. 2020, 56, 126835. [CrossRef]

4. Giedych, R.; Maksymiuk, G. Specific Features of Parks and Their Impact on Regulation and Cultural Ecosystem Services Provision in Warsaw, Poland. Sustainability 2017, 9, 792. [CrossRef]

5. Rackham, O. The History of the Countryside: The Full Fascinating Story of Britain's Landscape; Dent, J.M., Ed.; Sons Ltd.: London, UK, 1986.

6. MEA. Millennium Ecosystem Assessment. In Ecosystems and Human Well-Being: Synthesis; Island Press: Washington, DC, USA, 2005; p. 137. Available online: http://www.royalsocietyqld.org/wp-content/uploads/2017/11/MEA_Summary_Extract.pdf (accessed on 21 July 2021).

7. TEEB. The Economics of Ecosystem and Biodiversity. Ecological and Economic Foundation; Kumar, P., Ed.; Routledge: London, UK, 2010; p. 410.

8. Sykes, O.; Brown, J.; Cocks, M.; Shaw, D.; Couch, C. A City Profile of Liverpool. Cities 2013, 35, 299-318. [CrossRef]

9. Slavicek, L.C. New York City's Central Park (Building America: Then and Now), 1st ed.; Chelsea House Pub: New York, NY, USA, $2009 ;$ p. 120.

10. Barthel, S.; Colding, J.; Emqvist, T.; Folke, C. History and local management of a biodiversity-rich, urban cultural landscape. Ecol. Soc. 2005, 10, 1-27. [CrossRef]

11. Nowak, D.J.; Bodine, A.R.; Hoehn, R.E.; Edgar, C.B.; Riley, G.; Hartel, D.R.; Dooley, K.J.; Stanton, S.M.; Hatfield, M.A.; Brandeis, T.J.; et al. Houston's Urban. Forest, 2015; Resource Bulletin SRS-211; US Forest Service, Southern Research Station: Asheville, NC, USA, 2017. Available online: https:/ / www.researchgate.net/deref/http $\% 3 \mathrm{~A} \% 2 \mathrm{~F} \% 2 \mathrm{Fwww}$. srs.fs.usda.gov $\% 2 \mathrm{Fpubs} \% 2 \mathrm{~F}$ (accessed on 24 July 2021).

12. Colantoni, A.; Egidi, G.; Quaranta, G.; D’Alessandro, R.; Vinci, S.; Turco, R.; Salvati, L. Sustainable Land Management, Wildfire Risk and the Role of Grazing in Mediterranean Urban-Rural Interfaces: A Regional Approach from Greece. Land 2020, 9, 21. [CrossRef]

13. Davis, S. Urban foodscapes and greenspace design: Integrating grazing landscapes within multi-use urban parks. Front. Sustain. Food Syst. 2021, 5, 559025. [CrossRef]

14. Ranacher, L.; Sedmik, A.; Schwarzbauer, P. Public Perceptions of Forestry and the Forest-Based Bioeconomy in the European Union; Knowledge to Action 3; European Forest Institute: Joensuu, Finland, 2020; p. 104. [CrossRef]

15. Heyman, E. Analysing recreational values and management effects in an urban forest with the visitor-employed photography method. Urban. For. Urban. Green. 2012, 11, 267-277. [CrossRef]

16. Pelyukh, O.; Zachvoyska, L.; Paletto, A. Comparison between people's perceptions and preferences towards forest stand characteristics in Italy and Ukraine. Ann. Silvic. Res. 2019, 43, 4-14. 
17. Gundersen, V.; Köhler, B.; Myrvold, K.M. Seeing the Forest for the Trees: A Review-Based Framework for Better Harmonization of Timber Production, Biodiversity, and Recreation in Boreal Urban Forests. Urban. Sci. 2019, 3, 113. [CrossRef]

18. Lee, T.R. Perceptions, Attitudes and Preferences in Forests and Woodlands; Technical Paper-Forestry Commission 2001; CAB Direct: Edinburgh, UK; p. 166. Available online: https:/ / www.cabdirect.org/cabdirect/abstract/20023067232 (accessed on 21 July 2021).

19. Appleton, J. The Experience of Landscape; Wiley and Sons: London, UK, 1975; p. 293.

20. Orians, G.H.; Heerwagen, J.H. Evolved responses to landscapes. In The Adapted Mind: Evolutionary Psychology and The Generation of Culture; Barkow, J.H., Cosmides, L., Tooby, J., Eds.; Oxford University Press: New York, NY, USA, 1992; pp. 555-579.

21. Sommer, R. Further cross national studies of tree form preferences. Ecol. Psychol. 1997, 9, 153-160. [CrossRef]

22. Statistics Poland. Local Data Base. 2020. Available online: https:/ / bdl.stat.gov.pl/ (accessed on 16 July 2021).

23. Serwis Informacyjny Urzędu Miasta Rzeszowa (Information Service of the Rzeszów City Hall). Rozszerzenie Granic RZESZOWA. Available online: Erzeszow.pl (accessed on 16 July 2021).

24. Bonusiak, A. Terytoria przyłączone do Rzeszowa w pierwszym dziesięcioleciu XXI wieku, ich historia i stan dzisiejszy (Territories included to Rzeszów in the first decade of the 21st century, their history and present state). In Dzieje Rzeszowa. T. 5. Rzeszów w Latach 1989-2015 (The History of Rzeszów. Vol. 5. Rzeszów in the Years 1989-2015); Bonusiak, A., Ed.; Polskiej Bibliografii Naukowej: Rzeszów, Poland, 2017; pp. 55-102.

25. Bobiec, A.; Paderewski, J.; Gajdek, A. Urbanisation and globalised environmental discourse do not help to protect the bio-cultural legacy of rural landscapes. Landsc. Urban Plan. 2021, 208. [CrossRef]

26. Bobiec, A.; Reif, A.; Öllerer, K. Seeing the oakscape beyond the forest: A landscape approach to the oak regeneration in Europe. Landsc. Ecol. 2018, 33, 513-528. [CrossRef]

27. Zimnal, Z.; Tablica, I. Szkic geomorfologiczny. In Objaśnienia Do Szczegótowej Mapy Geologicznej Polski, Skala 1:50,000, Arkusz Rzeszów 982; Zimnal, Z., Malata, T., Eds.; PIG PIB: Warszawa, Poland, 2014.

28. Wójcik, T.; Ziaja, M.; Makuch, I.; Ćwik, A.; Kotańska, M. Vegetation of the Lisia Góra Reserve in Rzeszów. Fragm. Florist. Et Geobot. Pol. 2018, 25, 21-43.

29. Wójcik, T.; Makuch, I.; Ćwik, A.; Ziaja, M. Anthropogenic changes in selected elements of the natural environment in the Lisia Góra forest nature reserve in Rzeszów. Sylwan 2020, 164, 246-253. [CrossRef]

30. Bobiec, A.; Podlaski, R.; Ortyl, B.; Korol, M.; Havryliuk, S.; Öllerer, K.; Ziobro, J.K.; Pilch, K.; Dychkevych, K.; Dudek, T.; et al. Top-down segregated policies undermine the maintenance of traditional wooded landscapes: Evidence from oaks at the European Union's eastern border. Landsc. Urban Plan. 2019, 189, 247-259. [CrossRef]

31. Rinn, F. TSAP-WinTM Time Series Analysis and Presentation for Dendrochronology and Related Applications Version 0.53 for Microsoft Windows 98, 2000, XP; Rinntech: Heilderberg, Germany, 2003.

32. Rozas, V. Tree age estimates in Fagus sylvatica and Quercus robur: Testing previous and improved methods. Plant. Ecol. 2003, 167, 193-212. [CrossRef]

33. Snowarski, M. Atlas of Vascular Plants of Poland. Available online: http://www.atlas-roslin.pl/index.html (accessed on 21 April 2021).

34. Alien Species in Poland, 2009. Available online: http://www.iop.krakow.pl/ias/species (accessed on 14 July 2021).

35. Matuszkiewicz, W.A. Guide for Identification of Polish Plant. Communities; Polish Scientific Publishers PWN: Warsaw, Poland, 2017; p. 536.

36. Dzwonko, Z.; Loster, S. Wskaźnikowe gatunki roślin starych lasów i ich znaczenie dla ochrony przyrody i kartografii roślinności. Pr. Geogr. PAN 2001, 178, 119-132.

37. Pladias. Database of the Czech Flora and Vegetation. 2014-2019. Available online: http:/ / www.pladias.org (accessed on 14 July 2021).

38. Wójcik, T. Bogactwo florystyczne lasu "Ratośniówki" na Pogórzu Strzyżowskim. Chrońmy Przyr. Ojcz. 2012, 68, $26-35$.

39. Molnár, G.; Timár, G.; Biszak, E. Can The First Military Survey Maps of the Habsburg Empire (1763-1790) Be Georeferenced by An Accuracy of 200 Meters? In Proceedings of the 9th International Workshop on Digital Approaches to Cartographic Heritage, Budapest, Hungary, 4-5 September 2014; pp. 127-132. [CrossRef]

40. Projekt Parku Miejskiego w Rzeszowie Na Gruntach Miejskich Nad Wisłokiem. Lwów, 1937. Akta Miasta Rzeszowa (Files of The City of Rzeszów) 457/37; Polish State Archives: Rzeszów, Poland, 1937.

41. Kwartalny Biuletyn Informacyjny (Quarterly Information Bulletin) 1938; Kraków, Poland; p. 8. Available online: https:/ /jbc.bj.uj.edu. $\mathrm{pl} /$ dlibra/publication/401554/edition/379310 (accessed on 22 July 2021).

42. Kwartalny Biuletyn Informacyjny o Ochronie Przyrody (Quarterly Information Bulletin Concerning the Protection of Nature) 1939; Kraków, Poland; p. 9. Available online: https://jbc.bj.uj.edu.pl/dlibra/publication/401558/edition/379312 (accessed on 22 July 2021).

43. Ellenberger, H.; Weber, H.E.; Düll, R.; Wirth, V.; Werner, W.; Paulißen, D. Zeigerwerte von Pflanzen in Mitteleuropa. Scr. Geobot. 1992, 18. [CrossRef]

44. Vera, F.W.M. Grazing Ecology and Forest History; CABI Publishing: Wallingford, UK, 2000. [CrossRef]

45. Petritan, I.C.; Marzano, R.; Petritan, A.M.; Lingua, E. Overstory succession in a mixed Quercus petraea-Fagus sylvatica old growth forest revealed through the spatial pattern of competition and mortality. For. Ecol. Manag. 2014, 326, 9-17. [CrossRef]

46. Dolezal, J.; Leheckova, E.; Sohar, K.; Altman, J. Oak decline induced by mistletoe, competition and climate change: A case study from central Europe. Preslia 2016, 88, 323-346. 
47. Bobiec, A. The influence of gaps on tree regeneration: A case study of the mixed lime-hornbeam (Tilio-Carpinetum Tracz. 1962) communities in the Białowieża Primeval Forest. Pol. J. Ecol. 2007, 55, 441-455.

48. Bobiec, A.; Bobiec, M. Influence of spruce decline in stands of the Białowieża National Park on natural oak regeneration. Sylwan 2012, 156, 243-251. [CrossRef]

49. Kozłowska, A. The forest communities in the Przemyśl Foothils, south-east Poland. Fragm. Flor. Geobot. 2000, 45, $345-372$.

50. Towpasz, K.; Stachurska-Swakoń, A. Alder-ash and willow communities and their diversity in the Pogórze Strzyżowskie Foothills (Western Carpathians). Acta Soc. Bot. Pol. 2008, 77, 327-338.

51. Towpasz, K.; Stachurska-Swakon, A. Diversity of the forest communities from the Carpinion betuli and Fagion sylvaticae alliances in the Strzyżowskie Foothills, Western Carpathians. Fragm. Florist. Geobot. Polon. 2010, 17, 315-359.

52. Wójcik, T.; Rogus, A.; Ćwik, A. Plan communities in the "Św. Roch" forest in Rzeszów (Dynowskie Foothilla). Fragm. Florist. Geobot. Polon. 2016, 23, 101-120.

53. Wolański, P.; Bobiec, A.; Ortyl, B.; Makuch-Pietraś, I.; Czarnota, P.; Ziobro, J.; Korol, M.; Havryliuk, S.; Paderewski, J.; Kirby, K. The importance of livestock grazing at woodland-grassland interface in the conservation of rich oakwood plant communities in temperate Europe. Biodivers. Conserv. 2021, 30, 741-760. [CrossRef]

54. Close, F.; Berkes, J.; Colding, C.; Folke, C. Rediscovery of traditional ecological knowledge as adaptive management. Ecol. Appl. 2000, 10, 1251-1262. [CrossRef]

55. Soga, M.; Gaston, K.J. Shifting baseline syndrome: Causes, consequences, and implications. Front. Ecol. Environ. 2018, 16, 222-230. [CrossRef]

56. Lonsdale, D. Ancient and Other Veteran Trees: Further Guidance on Management; The Three Council: London, UK, $2013 ;$ p. 212.

57. Barthel, S.; Crumley, C.; Svedin, U. Bio-cultural refugia-Safeguarding diversity of practices for food security and biodiversity. Glob. Environ. Chang. 2013, 23, 1142-1152. [CrossRef] 